\title{
ODNOS DRŽAVLJANSTVA I NACIONALNE PRIPADNOSTI U KRALJEVINI SHS/JUGOSLAVIJI
}

Doc. dr. sc. Ivan Kosnica*

UDK: 323.1(497.1)“1918/1941“

342.71(497.1)“1918/1941“

Izvorni znanstveni rad

Primljeno: siječanj 2018.

Predmet rada je odnos državljanstva $i$ nacionalne pripadnosti u Kraljevini SHS/Jugoslaviji u razdoblju od osnivanja države 1918. godine pa sve do njezina poraza u travanjskom ratu 1941. godine. Osnovno je metodološko polazište istraživanja Tillyjeva klasifikacija prema kojoj postoje četiri osnovna tipa veze između državljanstva i nacionalne pripadnosti: isključujući izvorni, isključujući naučeni, uključujući izvorni i uključujući naučeni tip. Autor je u radu utvrdio da je u Kraljevini uspostavljen isključujući izvorni tip državljanstva koji sobzirom na primarno privilegiranje Srba, Hrvata i Slovenaca te u drugom stupnju i ostalih Slavena naziva isključujućim dvostupanjskim izvornim modelom. Autor također ističe $i$ postojanje određenih korekcija tog modela u pogledu isključivosti i izvornosti. Rad se u velikoj mjeri temelji na istraživanju arhivskoga gradiva dostupnog u Hrvatskom državnom arhivu.

Ključne riječi: nacionalna pripadnost, državljanstvo, Kraljevina SHS, Kraljevina Jugoslavija, Zakon o državljanstvu

\section{UVOD}

Državljanstvo je javnopravna veza između pojedinca i države koju karakterizira međusoban odnos prava i obaveza. ${ }^{1}$ Nacionalna pripadnost jest pripadnost

* Dr. sc. Ivan Kosnica, docent Pravnog fakulteta Sveučilišta u Zagrebu, Sv. Ćirila i Metoda 4, Zagreb; ikosnica@gmail.com;

ORCID ID: orcid.org/0000-0002-0467-6062

1 Državljanstvo je stoga višedimenzionalan pojam koji uključuje dimenziju statusa, prava i obveza i identitetsku dimenziju. Usporedi Joppke, C., Transformation of Citizenship: Status, Rights, Identity, Citizenship Studies, vol. 11, br. 1, 2007., str. 38; 
pojedinca naciji. Naciju možemo definirati kao kolektiv sastavljen od pojedinaca koje karakterizira osjećaj pripadnosti grupi temeljen na svijesti o zajedničkoj prošlosti, običajima i jeziku. ${ }^{2}$ Koncepti državljanstva i nacionalne pripadnosti mogu biti u različitom odnosu. Pri tome je za analizu tog odnosa osobito pogodna klasifikacija koju je osmislio Charles Tilly. Prema Tillyju moguće je razlikovati četiri tipa državljanstva: isključujući izvorni, isključujući naučeni, uključujući izvorni i uključujući naučeni tip. Bitna karakteristika isključujućeg izvornog tipa jest u tome što je kod tog tipa izvorna pripadnost pojedinoj naciji temeljni preduvjet za ulazak u zajednicu državljana. Prema Tillyju klasičan primjer države u kojoj je odnos državljanstva i nacije uređen prema tom modelu je Izrael. Kod drugog isključujućeg naučenog tipa ne traži se izvorna pripadnost specifičnoj nacionalnoj grupi, nego je osnova za ulazak u zajednicu državljana usvajanje točno određenih obrazaca ponašanja. Tipičan primjer za taj tip odnosa između državljanstva i nacije je Francuska. Treći je uključujući izvorni tip. Bitna karakteristika tog tipa je u tome da je pripadnost zajednici državljana izvorno utemeljena na pripadnosti specifičnoj nacionalnoj grupi, ali uz toleriranje pripadnika drugih etničkih grupa bez obaveze usvajanja točno određenog obrasca ponašanja. Tipičan primjer za ovaj tip je Osmansko Carstvo. Konačno, četvrti je uključujući naučeni tip. Za taj je tip karakteristično da se ne traži izvorna pripadnost specifičnoj etničkoj grupi te da je ulazak u zajednicu državljana moguć na temelju usvajanja raznih oblika prihvatljivog ponašanja. Tipičan primjer jesu Sjedinjene Američke Države. ${ }^{3}$

Prethodno izloženu Tillyjevu klasifikaciju koristit ćemo u istraživanju odnosa državljanstva i nacionalne pripadnosti u Kraljevini SHS/Jugoslaviji, teme

Jenson, J., Place-Sensitive Citizenship: The Canadian Citizenship Regime until 1945, u: Hoerder, D.; Harzig, C.; Shubert A., The Historical Practice of Diversity: Transcultural Interactions from the Early Modern Mediterranean to the Postcolonial World, Berghahn Books, New York, Oxford, 2003., str. 225 - 226.

2 Osnovno o naciji vidi u: Banac, I., Nacionalno pitanje u Jugoslaviji: porijeklo, povijest, politika, Globus, Zagreb, 1988., str. 31 - 40. O naciji i nacionalizmu vidi: Tilly, C., The Emergence of Citizenship in France and Elsewhere, u: Tilly, C. (ed.), Citizenship, Identity and Social History, International Review of Social History, Cambridge University Press, Cambridge, 1996., str. 231 - 233. Za teorijska razilaženja u pogledu nacije vidi: Katunarić, V., Sporna zajednica: novije teorije o naciji i nacionalizmu, Jesenski i Turk, Hrvatsko sociološko društvo, Zagreb, 2003., str. 139 - 312; Smith, A. D., Nacionalizam i modernizam: kritički pregled suvremenih teorija nacija i nacionalizma, Politička misao, Zagreb, 2003., str. 226 - 229.

3 Tilly, C., Citizenship, Identity and Social History, u: Tilly, C. (ed.), Citizenship, Identity and Social History, International Review of Social History, Cambridge University Press, Cambridge, 1996., str. $10-11$. 
koja je još nedovoljno istražena u pravnopovijesnoj znanosti. ${ }^{4}$ Pri tome osobito vrijednim smatramo istaknuti da ćemo se u sklopu istraživanja u velikoj mjeri koristiti arhivskim fondovima dostupnima u Hrvatskom državnom arhivu te osobito vrijednom arhivskom zbirkom personalija Banovine Hrvatske koja sadržava brojne dosjee o naturalizacijama, molbama i opcijama na hrvatskim područjima u Kraljevini SHS/Jugoslaviji za razdoblje od 1918. do 1941. godine, u sklopu koje su dostupna i brojna rješenja Ministarstva unutrašnjih poslova Kraljevine SHS/Jugoslavije u Beogradu.

Osnovno je polazište u radu da je u Kraljevini SHS/Jugoslaviji između državljanstva i nacionalne pripadnosti uspostavljena bliska veza, posebno s obzirom na činjenicu da je Kraljevina SHS idejno zamišljena kao država utemeljena na nacionalnom načelu. Ipak stvarne razmjere veze između državljanstva i nacionalne pripadnosti te pozicioniranje Kraljevine SHS/Jugoslavije u Tillyjevu shemu moguće je utvrditi tek nakon detaljnog istraživanja odnosa između državljanstva i nacionalne pripadnosti.

Da bismo spoznali taj odnos, uvodno ćemo u osnovnim crtama prikazati odnos državljanstva i nacionalne pripadnosti na teritorijima koji su ušli u sastav Kraljevine SHS 1918. godine. Zatim se daju osnovne napomene o uspostavi Kraljevine SHS, nacionalnim razlikama i državljanstvu. Dalje se razmatra pitanje u kojoj su mjeri mirovni ugovori bili značajni za jačanje veze između državljanstva i nacionalne pripadnosti. Nakon toga se analiziraju pojedine naturalizacije u upravnoj praksi u razdoblju do donošenja Zakona o državljanstvu 1928. godine, analizira se važnost nacionalne pripadnosti u Zakonu o državljanstvu iz 1928. godine te se naposljetku na temelju prakse naturalizacija analizira odnos između državljanstva i nacionalne pripadnosti u razdoblju od 1928. do 1941. godine.

4 Suprotno tome, za europsko okruženje postoje brojna istraživanja odnosa između državljanstva i nacije. Usporedi Brubaker, R., Citizenship and Nationhood in France and Germany, Harvard University Press, Cambridge, Massachusetts and London, England, Second printing, 1994.; Gosewinkel, D., Einbürgern und Ausschliessen: Die Nationalisierung der Staatsangehörigkeit vom Deutschen Bund bis zur Bundesrepublik Deutschland, Vandenhoeck \& Ruprecht, Göttingen, 2003.; Fahrmeir, A., Citizenship: The Rise and Fall of a Modern Concept, Yale University Press, New Haven and London, 2007., str. 89 - 123; Weil, P., How to be French: Nationality in the Making since 1789, Duke University Press, Durham and London, 2008., str. 60 - 63, 85 - 124; Sammartino, A., After Brubaker: Citizenship in Modern Germany, 1848 to Today, German History, vol. 27, br. 4, 2009., str. 583 - 599. 


\section{ODNOS DRŽAVLJANSTVA I NACIONALNE PRIPADNOSTI UOČI NASTANKA KRALJEVINE SHS: TRADICIJA}

Osnovni prikaz zatečene tradicije u Kraljevini SHS, s obzirom na odnos državljanstva i nacionalne pripadnosti, podrazumijeva prikaz tog odnosa na šest pravnih područja: slovensko-dalmatinskom području, bivšem ugarskom području, hrvatsko-slavonskom području, bosansko-hercegovačkom području, području bivše Kraljevine Srbije te području bivše Kraljevine Crne Gore.

Na slovensko-dalmatinskom području institut državljanstva bio je reguliran odredbama austrijskog Općeg građanskog zakonika te popratnim dekretima. ${ }^{5}$ Navedenim propisima institut državljanstva nije bio nacionalno određen, a nacionalni kriterij nije bio ključan prilikom naturalizacija sve do početka Prvog svjetskog rata. ${ }^{6}$ Izbijanjem Prvog svjetskog rata nacionalna pripadnost postala je značajna kod naturalizacija, a upravne vlasti u praksu su uvele mjere koje su imale za cilj ispitati nacionalni osjećaj državljana. ${ }^{7}$ Analiziramo li odnos državljanstva i nacionalne pripadnosti kroz prizmu Tillyjeva modela, možemo konstatirati da je na bivšem austrijskom području Austro-Ugarske Monarhije uspostavljen odnos između austrijskog državljanstva i nacije koji nije nužno tražio pripadnost osobe jednoj nacionalnoj grupi te koji ne karakterizira samo jedan prihvatljiv obrazac ponašanja. Drugim riječima, uspostavljen je odnos najsličniji uključujućem naučenom tipu. Tijekom Prvog svjetskog rata u praksu uvedeni kriteriji nacionalne pripadnosti doveli su do pomaka od uključujućeg naučenog tipa prema isključujućem izvornom tipu.

Na bivšem ugarskom području na snazi su bile odredbe Zakona o stjecanju i gubitku ugarskog državljanstva iz 1879. godine. ${ }^{8}$ Navedeni zakon nije sadržavao kriterij nacionalne pripadnosti kao značajan za naturalizaciju, a također nije sadržavao ni kriterij poznavanja jezika ili neki drugi kriterij primjena kojeg bi

5 Štiks, I., Nations and Citizens in Yugoslavia and the Post-Yugoslav States: One Hundred Years of Citizenship, Bloomsbury, London - New York, 2015., str. 32.

6 Hirschhausen, U., From imperial inclusion to national exclusion: citizenship in the Habsburg monarchy and in Austria 1867-1923, European Review of History - Revue européenne d'histoire, vol. 16, br. 4, 2009., str. 557.

7 Hirschhausen, op. cit. u bilj. 6, str. 557 - 559; Healy, M., Becoming Austrian: Women, the State, and Citizenship in World War I, Central European History, vol. 35, br. 1, 2002., str. $13-19$.

8 Zakonski članak L.:1879. zajedničkoga hrvatsko-ugarskoga sabora o stečenju i gubitku ugarskoga državljanstva, Sbornik zakonah i naredabah valjanih za kraljevinu Hrvatsku i Slavoniju, komad VII, 1880. 
podrazumijevala prethodnu "kulturnu" prilagodbu stranaca.9 S obzirom na to, odnos državljanstva i nacionalne pripadnosti možemo okarakterizirati kao uključujući naučeni tip. Bitne promjene u tom odnosu nastupile su, međutim, tijekom zadnjih dvaju desetljeća 19. stoljeća i početkom 20. stoljeća, kad bilježimo snažne procese mađarizacije koje su provodile ugarske vlasti s ciljem pretvaranja Ugarske u nacionalnu državu Mađara. ${ }^{10} \mathrm{Ti}$ su procesi rezultirali jačanjem veze između državljanstva i nacionalne pripadnosti. ${ }^{11}$ Imamo li u vidu Tillyjevu klasifikaciju, možemo reći da je s obzirom na naglašavanje veze između mađarske nacije i državljanstva potkraj 19. stoljeća i početkom 20. stoljeća došlo do pomicanja od uključujućeg naučenog tipa prema isključujućem izvornom tipu.

Na hrvatsko-slavonskom području državljanstvo je također bilo uređeno Zakonom o stjecanju i gubitku ugarskog državljanstva iz 1879. godine. U upravnoj praksi državljanstvo je nazivano ugarsko-hrvatskim, a pravo dodjele državljanstva sa zavičajnošću u Hrvatskoj i Slavoniji imao je hrvatsko-slavonski ban (čl. 11.). Navedeni je zakon, kako smo već naglasili, odnos državljanstva i nacionalne pripadnosti uredio na način koji je bio najsličniji uključujućem naučenom tipu. Zakon je, s obzirom na činjenicu da nije sadržavao etničke kriterije ni kriterij jezika ili "kulturne" prilagodbe, bio pogodan za primjenu i na prostoru Hrvatske i Slavonije. Analiza pojedinih naturalizacija u vremenu od 1880. godine pa sve do pred Prvi svjetski rat pokazuje da nacionalna pripadnost nije bila ključna za naturalizaciju, nego da je do porasta važnosti nacionalne pripadnosti došlo tek za vrijeme Prvog svjetskog rata. ${ }^{12} \mathrm{~S}$ obzirom na navedeno, na hrvatsko-slavonskom području možemo govoriti o odnosu između državljanstva i nacionalne

9 Stoga je u pravu bio opozicijski političar Nándor Szederkény kad je u raspravi o prijedlogu zakona o državljanstvu vođenoj na Ugarsko-hrvatskom saboru 1879. godine prigovorio tezi vladajućih da je prijedlog zakona u skladu s "mađarskom prirodom”, istaknuvši da je riječ o zakonu koji “potiče kozmopolitizam”. Raspravu o zakonu vidi u: Varga, N., The Framing of the First Hungarian Citizenship Law (Act 50 of 1879) and the Acquisition of citizenship, Hungarian Studies, vol. 18, br. 2, 2004., str. $130-131$.

10 Macartney, C. A., The Habsburg Empire, Weidenfeld and Nicolson, London, 1971., str. $721-734$.

11 Hirschhausen, op. cit. u bilj. 6, str. 563 - 564.; Gammerl, B., Subjects, citizens and others: the handling of ethnic differences in the British and the Habsburg Empires (late nineteenth and early twentieth century), European Review of History - Revue européenne d'histoire, vol. 16, br. 4, 2009., str. 527.

12 Usporedi Kosnica, I., Naturalizacija u Hrvatskoj i Slavoniji od 1848. do 1918., Zbornik Pravnog fakulteta Sveučilišta u Rijeci, vol. 34, br. 2, 2013., str. 722 - 725; Kosnica, I., Citizenship in Croatia-Slavonia during the First World War, Journal on European History of Law, vol. 8, br. 1, 2017., str. $63-65$. 
pripadnosti koji je najbliži uključujućem naučenom tipu uz ogradu da su tijekom Prvog svjetskog rata u praksu uvedeni isključujući kriteriji primjenom kojih je u shemi odnosa između državljanstva i nacionalne pripadnosti došlo do pomicanja prema isključujućem izvornom tipu.

$\mathrm{Na}$ bosansko-hercegovačkom području javnopravni status osoba bio je određen bosansko-hercegovačkom pripadnošću. Propis kojim je regulirana ta pripadnost bio je nacionalno neutralan. ${ }^{13}$ Pravni poredak Bosne i Hercegovine karakterizirala je multietničnost te multikonfesionalnost uz toleriranje više prihvatljivih kulturnih obrazaca. ${ }^{14} \mathrm{~S}$ obzirom na sve navedeno, odnos između bosansko-hercegovačke pripadnosti i nacionalne pripadnosti bio je najbliži uključujućem naučenom tipu. Bitne promjene u tom odnosu nastupile su tek za vrijeme Prvog svjetskog rata kad je s obzirom na rat Austro-Ugarske Monarhije s Kraljevinom Srbijom došlo do uvođenja isključujućih kriterija u praksu s obzirom na sumnju vlasti Monarhije u lojalnost dijela srpskog stanovništva, a to je u konačnici dovelo do pomicanja u shemi prema isključujućem izvornom tipu.

Na području bivše Kraljevine Srbije vrlo su značajne bile odredbe srbijanskog Građanskog zakonika te uredba o naturalizaciji i otpustu iz državljanstva. ${ }^{15} \mathrm{U}$ Srbiji se građanstvo u pravilu stjecalo rodom (ius sanguinis). ${ }^{16} \mathrm{~S}$ obzirom na uspostavu Kraljevine Srbije kao srpske nacionalne države, uspostavljena je bliska veza između državljanstva i nacionalne pripadnosti te stoga u tom slučaju možemo govoriti o isključujućem izvornom tipu. Bitno ograničenje tog tipa državljanstva bile su odredbe Berlinskog ugovora iz 1878. godine kojima je Srbiji nametnuta obveza jamstava ravnopravnosti različitim vjerskim zajednicama. ${ }^{17}$ Navedena obaveza ublažavala je isključujući izvorni tip državljanstva te ga približavala uključujućem izvornom tipu.

13 Tezu o etničkoj neutralnosti bosansko-hercegovačke pripadnosti vidi u: Gammerl, op. cit. u bilj. 11, str. 531 .

14 Multietničnost i multikonfesionalnost došli su do izražaja i u Ustavu iz 1910. godine te u izbornim propisima. Ibid., str. 532.

15 Relevantan tekst Građanskog zakonika Kraljevine Srbije i Uredbe o srpskom prirođenju i otpuštanju Srba iz njihovog otačstva od 2. svibnja 1844. godine VNo. 603. vidi u: Tepić, Đ.; Bašić, I., Zbirka propisa o državljanstvu, Narodne novine, Zagreb, 1969., str. $277-281$.

16 Usporedi čl. 44. Građanskog zakonika Kraljevine Srbije; Uredbom o srpskom prirođenju i otpuštanju Srba iz njihovog otačstva od 2. svibnja 1844. detaljno je uređeno primanje stranaca u srpsko državljanstvo naturalizacijom na temelju molbe podnesene Ministarstvu unutrašnjih djela. Usporedi čl. 2. i 3. Uredbe o srpskom prirođenju i otpuštanju Srba iz njihovog otačstva od 2. svibnja 1844.

$17 \mathrm{Su}, \mathrm{A} .$, Woodrow Wilson and the Origins of the International Law of Religious Freedom, Journal of the History of International Law, vol. 15, br. 2, 2013., str. 259. 
$\mathrm{Na}$ području bivše Kraljevine Crne Gore nisu postojali moderni propisi o državljanstvu, nego samo ustavna odredba o dodjeli državljanstva strancima. ${ }^{18}$ Ustavnopravni razvoj Crne Gore bio je donekle sličan razvoju Kraljevine Srbije u smislu da je Berlinskim ugovorom Crna Gora uspostavljena kao nacionalna država Crnogoraca uz obvezu jamstava prava vjerskim manjinama. S obzirom na navedeno, odnos državljanstva i nacionalne pripadnosti možemo okarakterizirati, slično kao i u Kraljevini Srbiji, kao tip koji je isključujući izvorni tip s određenim obilježjima uključujućeg izvornog tipa.

\section{USPOSTAVA KRALJEVINE SHS, NACIONALNE RAZLIKE I DRŽAVLJANSTVO}

Nakon završetka Prvog svjetskog rata, 1. prosinca 1918. godine, ujedinjenjem Države SHS s Kraljevinom Srbijom i Crnom Gorom uspostavljena je Kraljevina Srba, Hrvata i Slovenaca. Kao ideološka okosnica te države promoviran je koncept troplemenog naroda Srba, Hrvata i Slovenaca, vidljiv i u samom nazivu države. ${ }^{19}$ Ipak, s Hrvatima, Srbima i Slovencima u Kraljevini SHS živjeli su i brojni pripadnici drugih nacija. Tako su u Kraljevini živjeli i Crnogorci i Makedonci kao južnoslavenski narodi čija posebnost nije priznata. Nadalje u Kraljevini je živio i relativno velik broj izbjeglica iz Sovjetskog Saveza, otprilike 60000 Rusa. U istočnom dijelu Kraljevine vrlo brojni i u vrlo lošem položaju bili su Albanci, dok su također vrlo značajna grupa bili Židovi. Također, u Kraljevini je na područjima koja su do 1918. godine bila u sklopu Austro-Ugarske Monarhije živio i značajan broj Mađara te Nijemaca koji su od dominantnih nacija postali stanovnici i državljani dvojbene lojalnosti. ${ }^{20}$

18 Štiks, op. cit. u bilj. 5, str. 32; usporedi čl. 120. toč. 7. Ustava Kneževine Crne Gore iz 1905. godine kojim je propisana ovlast Državnog savjeta "da odobrava izuzetno stupanje u crnogorsko državljanstvo". Tekst Ustava dostupan je na: http://www. montenegrina.net/pages/pagesl/istorija/dokumenti/Ustav\%20Crne\%20Gore\%20 iz\%201905.pdf (1. siječnja 2018.).

19 Glavne zagovornice tog koncepta bile su Srpska radikalna stranka i Demokratska stranka. Pri tome su između tih stranaka bile vidljive i određene razlike. Srpska radikalna stranka je bila više sklona troplemenskoj koncepciji, dok je Demokratska stranka na toj osnovi gradila ideologiju integralnog jugoslavenstva. Usporedi Troch, P., Yugoslavism between the world wars: indecisive nation building, Nationalities Papers, vol. 38, br. 2, 2010., str. $229-232$.

20 Goldstein, I., Hrvatska 1918-2008., EPH Liber, Zagreb, 2008., str. 68 - 71. Kod Mađara i Nijemaca došlo je do tzv. etničkog obrata na način da su te manjine izgubile povlašten položaj koji su imale u razdoblju do 1918. godine. Sintagma etnički obrat preuzeta je iz: Riga, L.; Kennedy, J., Tolerant majorities, loyal minorities and "ethnic 
Za razliku od nacionalne heterogenosti nove države, pa i činjenice da je Kraljevina SHS bila formirana od zemalja koje nisu dijelile istu tradicijsku baštinu, u Kraljevini SHS već nakon njezina osnutka promovirana je dogma jednog državljanstva. Osnovna ideološka podloga takvog rješenja bila je koncepcija jedinstvenog naroda sastavljenog od triju plemena. $U$ administrativnom smislu koncept jedinstvenog državljanstva podržavale su upravne vlasti već tijekom 1919. godine. ${ }^{21}$ Konačno je načelo jedinstvenog državljanstva proklamirano i u Ustavu Kraljevine SHS iz 1921. godine (čl. 4.). ${ }^{22}$ Zakon o državljanstvu nije međutim donesen sve do 1928. godine, pa su na svakom od pravnih područja u osnovi nastavili važiti raniji propisi o državljanstvu.

Analiza odnosa između državljanstva i nacionalne pripadnosti nakon osnutka Kraljevine SHS pokazuje u praksi prisutno usmjerenje prema kojem je državljanstvo barem dijelom nacionalno određeno. Tako je još za vrijeme Države SHS Narodno vijeće izdalo naredbu prema kojoj članovi narodnih odbora "mogu biti samo Srbi, Hrvati i Slovenci te ostali Slaveni, ali Nijemci i Mađari nikako". ${ }^{23}$ Nastankom Kraljevine SHS nastavljen je trend jačanja veze između državljanstva i nacionalne pripadnosti. Pri tome u osnovi treba razlikovati dva čimbenika koji su utjecali na to. Prvi su čimbenik grupe građana koje su promjenu režima vidjele kao priliku za obračun sa "stranim elementom". ${ }^{24}$ Drugi

reversals": constructing minority rights at Versailles, Nations and Nationalism, vol. 15, br. 3, 2009., str. 461.

21 Tako je Zemaljska vlada za Hrvatsku i Slavoniju u jednoj odluci iz 1919. godine jasno dala do znanja da koncept hrvatsko-slavonske zemaljske pripadnosti više nije značajan za status pojedinaca, čime je implicite priznat koncept jedinstvenog državljanstva. HR HDA, Pokrajinska uprava za Hrvatsku i Slavoniju u Zagrebu, Odjeljenje za unutarnje poslove (dalje u tekstu: HDA PU OU), sv. V-2 62501/1922. Vidi i: HDA PU OU, sv. V-3 18914/1922 (izvještaj Zemaljske vlade povjereništva za unutarnje poslove broj 39492/1919 od 9. rujna 1919. godine).

22 Ustav Kraljevine Srba, Hrvata i Slovenaca, obnarodovan u br. 142a Službenih novina na Vidovdan 28. lipnja 1921. god. u Beogradu, Državna štamparija Kraljevine Srba, Hrvata i Slovenaca, Beograd, 1926.

23 Goldstein, op. cit. u bilj. 20, str. 20.

24 Dobar primjer za navedeno jesu predstavke građana upućene vlastima protiv imućnih veleposjednika iz Mađarske u Slavoniji. Ilustrativan je u tom smislu predmet utvrđivanja državljanstva obitelji Gutmann započet 1919. godine na poticaj grupe građana te umirovljenog općinskog bilježnika Ilije Stojšića. HDA PU OU, sv. V-3 18914/1922 (izvještaj Zemaljske vlade povjereništva za unutarnje poslove broj 39492/1919 od 9. rujna 1919. godine). Vidi i predmet utvrđivanja državljanstva grofa Majlatha u kojem su žitelji Čađavice protestirali protiv toga da grofu Majlathu bude utvrđeno državljanstvo Kraljevine SHS te su tom prigodom isticali da je on “po osjećaju Mađar”, da je na "svoje vlastelinstvo namještao Mađare kao činovnike 
je čimbenik djelovanje upravnih vlasti koje su u upravnim postupcima uzimale u obzir i kriterije narodne pripadnosti i jezika. ${ }^{25}$ Iz svega navedenog vidljivo je da je veza između državljanstva i nacionalne pripadnosti bila vrlo značajna prilikom uspostave Kraljevine SHS.

\section{MIROVNI UGOVORI I NACIONALIZACIJA DRŽAVLJANSTVA}

Mirovni ugovori sklopljeni na Pariškoj mirovnoj konferenciji s Austrijom, Mađarskom i Bugarskom tijekom 1919. i 1920. godine sadržavali su značajne odredbe o državljanstvu. Svakako jedno od temeljnih pravila iznimno važno za tzv. početno određenje državljanskog tijela Kraljevine SHS u odnosu prema Austriji i Mađarskoj bilo je pravilo prema kojem su državljani Kraljevine svi koji su na njezinu teritoriju stekli zavičajnost do 1. siječnja 1910. godine te su je zadržali do stupanja mirovnih ugovora na snagu. ${ }^{26}$ Ugovorom s Bugarskom ključan datum za određenje državljanstva bio je 1. siječnja 1913. godine, a državljanstvo Kraljevine SHS stekli su svi koji su se do tog dana naselili na teritoriju koji je ušao u sastav Kraljevine SHS. ${ }^{27}$

Za sve koji su zavičajnost na teritoriju Kraljevine SHS stekli nakon 1. siječnja 1910. godine mirovnim ugovorima i provedbenim propisima predviđena je mogućnost stjecanja državljanstva Kraljevine SHS na temelju molbe. U takvim slučajevima zainteresirani su trebali podnijeti molbu prvostupanjskim upravnim vlastima Kraljevine SHS, a o zahtjevu je bila nadležna odlučiti Pokrajinska vlada odnosno Pokrajinska uprava. ${ }^{28}$

i kao sluge" i da je do 1918. godine podupirao mađarizaciju hrvatskih krajeva. HDA PU OU, sv. V-3 5708/1922 (dopis žitelja Čađavice od 1. lipnja 1922. godine).

25 Vidi zahtjev Ministarstva unutrašnjih djela postavljen podređenim upravnim organima kojim se traži očitovanje o rasnoj pripadnosti i materinjem jeziku grofa Eugena Festetića iz Čakovca, a sve s obzirom na mogućnost ukidanja sekvestra nad njegovim imanjem. HDA PU OU, sv. V-2 3649/1922.

26 Usporedi čl. 76. Ugovora o miru s Austrijom; usporedi čl. 62. Mirovnog ugovora s Ugarskom. Relevantan tekst mirovnih ugovora s Austrijom i Ugarskom te propise bitne za izvršenje mirovnih ugovora vidi u: Pirkmajer, O., Zakon o državljanstvu sa tumačenjem, Gece Kona, Beograd, 1929., str. 226 - 301.; Čepulo, D., Prava građana i moderne institucije: europska i hrvatska pravna tradicija, Pravni fakultet Sveučilišta u Zagrebu, Zagreb, 2003., str. 86.

27 Usporedi čl. 39. Mirovnog ugovora s Bugarskom. Relevantan tekst mirovnog ugovora s Bugarskom vidi u: Pirkmajer, op. cit. u bilj. 26, str. $302-313$.

28 U Kraljevoj uredbi iz 1920. godine korišten je naziv Pokrajinska vlada, dok je u Naredbi ministra unutrašnjih djela iz 1921. godine, donesenoj nakon stupanja na snagu Vidovdanskog ustava, korišten naziv Pokrajinska uprava. Usporedi čl. 2. - 4. 
Mirovnim ugovorima s Austrijom i Mađarskom predviđena su i dva tipa opcije, opcija na temelju ranije zavičajnosti i opcija na temelju narodnosti i jezika. Kod prvog tipa opcije riječ je o mogućnosti opcije za državu u kojoj se nalazila ranija zavičajna općina osobe. ${ }^{29} \mathrm{U}$ osnovi je ovdje bila riječ o mogućnosti svojevrsne repatrijacije na temelju ranije zavičajnosti.

Druga vrsta opcije je opcija za matičnu državu određenu na temelju narodnosti i jezika. Prema tekstu mirovnih ugovora zaključenih s Austrijom i Mađarskom tu su mogućnosti imali zavičajnici "koji se razlikuju od većine stanovništva po rasi i po jeziku”, dok je u ugovoru o miru s Bugarskom izbjegnuta formulacija rase te je korišten pojam narodnosti (čl. 40.). ${ }^{30}$ Kraljevom uredbom od 25. studenoga 1920. godine o stjecanju i gubitku državljanstva Kraljevine Srba, Hrvata i Slovenaca putem opcije i molbe i Naredbom ministra unutrašnjih poslova o postupanju pri stjecanju i gubitku državljanstva Kraljevine Srba, Hrvata i Slovenaca putem opcije i molbe donesenom 30. kolovoza 1921. godine detaljno je uređen institut stjecanja državljanstva na temelju opcije za matičnu državu na temelju narodnosti i jezika. Navedenim propisima predviđena je opcija za državljanstvo Kraljevine SHS za sve zavičajnike iz austrijskog odnosno ugarskog dijela Monarhije koji nisu ušli u sastav Kraljevine SHS pod pretpostavkom da su navršili 18 godina i da su "plemena i jezika Srpskog, Hrvatskog i Slovenskog". ${ }^{31}$ Podnositelj zahtjeva za opcijom je među ostalim trebao izjaviti i po potrebi dokazati činjenicu da mu je hrvatski, srpski odnosno slovenski jezik materinski jezik te je trebao dokazati da je Srbin, Hrvat odnosno Slovenac "po porijeklu i jeziku", a u tu svrhu je zahtjevu mogao priložiti školske svjedodžbe, potvrde o članstvu u srpskim, hrvatskim i slovenskim udrugama te potvrdu vjerodostojnih osoba o svojem porijeklu. ${ }^{32}$

S obzirom na sve navedeno možemo zaključiti da je pravilima o opciji za matičnu državu na temelju narodnosti i jezika u pravnom poretku više nego

Kraljeve uredbe od 25. studenoga 1920. godine O stjecanju i gubitku državljanstva Kraljevine Srba, Hrvata i Slovenaca putem opcije i molbe. Usporedi čl. 2. - 4. Naredbe ministra unutrašnjih djela od 30. kolovoza 1921. godine O postupanju pri stjecanju $i$ gubitku državljanstva Kraljevine SHS putem opcije i molbe. Tekst uredbe i naredbe vidi u: Pirkmajer, op. cit. u bilj. 26, str. $244-266,283-301$. Usporedi čl. 78. Ugovora o miru s Austrijom; čl. 63. Ugovora o miru s Mađarskom. Usporedi čl. 80. Ugovora o miru s Austrijom; usporedi čl. 64. Ugovora o miru s Mađarskom; Čepulo, op. cit. u bilj. 26, str. 86.

31 Usporedi čl. 11. Kraljeve uredbe od 25. studenoga 1920; usporedi čl. 10. Naredbe ministra unutrašnjih djela od 30. kolovoza 1921.

32 Usporedi čl. 13. Kraljeve uredbe od 25. studenoga 1920.; usporedi čl. 11. Naredbe ministra unutrašnjih djela od 30. kolovoza 1921. 
ranije naglašena veza između državljanstva i nacionalne pripadnosti. "Odgovarajuća" narodna pripadnost tako je bila osnova za podnošenje zahtjeva za ulazak u zajednicu državljana. Niz pojedinačnih slučajeva opcije zaista upućuje na zaključak da su kriteriji nacionalne pripadnosti i jezika bili vrlo važni da bi opcija bila pozitivno riješena. ${ }^{33}$ Suprotno navedenom, podnositelji opcija koji nisu udovoljavali nacionalnom kriteriju bili su izloženi velikoj vjerojatnosti odbijanja. Ilustrativan je predmet željezničkog činovnika Julija Aignera, mađarskog državljanina, koji je nakon prevrata 1918. godine ostao u Zagrebu te je podnio zahtjev upravnim vlastima za stjecanje državljanstva Kraljevine SHS na temelju opcije. Pri tome mu je Pokrajinska uprava za Hrvatsku i Slavoniju odbila dodijeliti državljanstvo stoga što "se ne može smatrati Srbinom, Hrvatom ili Slovencem po plemenu" te s obzirom na činjenicu da je rođen u Szentesu "od roditelja koji nisu jugoslavenskog porijekla" ${ }^{34}$

Svojevrsna korekcija primjene nacionalnog načela bilo je "nacionalno" neutralno pravilo prema kojem su za državljane Kraljevine SHS biti priznati svi koji su do 1. siječnja 1910. stekli zavičajnost na teritorijima koji su bili u sastavu Austro-Ugarske Monarhije odnosno koji su se do l. siječnja 1913. godine naselili na teritorijima koji su prethodno bili u sastavu Bugarske. Također bitna korekcija primjene nacionalnog načela trebao je biti i propis o zaštiti manjina, donesen zajedno s mirovnim ugovorima na poticaj sila pobjednica u Prvom svjetskom ratu. ${ }^{35}$ Propis o zaštiti manjina na snazi u Kraljevini SHS od 1920.

33 Za primjer pozitivno riješene opcije vidi predmet Marije Pirjevec, Slovenke, privatne namještenice iz Čakovca. HDA PU OU, sv. V-2/1922, 813/1922; vidi i predmet Franje Tončića. HR Hrvatski državni arhiv, Zagrebačka oblast, Veliki župan (dalje u tekstu: HDA ZO VŽ), IV-1 5117/1926; vidi i predmet Marka Pettka. Njegovoj opciji udovoljeno je stoga što je dokazao da se ranije smatrao Hrvatom, što mu je materinski jezik hrvatski i što je potvrdom dviju vjerodostojnih osoba potvrđeno da se smatrao Hrvatom. HDA ZO VŽ, IV-1 54762/1926.

34 HR Hrvatski državni arhiv, Zbirka personalija Banovine Hrvatske, fond 890 (dalje u tekstu: HDA ZP BH), dosje 27076 (Aigner); vidi i odbijenu opciju Arminu Braunu, čehoslovačkom državljaninu, stoga što "nije imao zavičajnost na kojoj teritoriji bivše Austro-Ugarske Monarhije što je pripala našoj Kraljevini i jer se ne može smatrati Srbinom, Hrvatom ili Slovencem po plemenu". Upravne vlasti u spisu konstatiraju da se optant rodio u Rajeczu (Čehoslovačka) i da je tamo zavičajan te da njegovi roditelji “nisu jugoslavenskog porijekla.” HDA PU OU, sv. V-2 8357/1922.

35 Propisi o zaštiti manjina nametnuti su Austriji, Mađarskoj, Poljskoj, Čehoslovačkoj, Kraljevstvu SHS, Rumunjskoj, Bugarskoj, Grčkoj i baltičkim državama. Fink, C., The Paris Peace Conference and the Question of Minority Rights, Peace \& Change, vol. 21, br. 3, 1996., str. 280. Svrha tih propisa bila je zaštita manjina u novonastalim nacionalnim državama. Pri tome su za razliku od mirovnog ugovora sklopljenog u Berlinu 1878. godine u kojem je ključno bilo poštovanje ravnopravnosti vjerskih za- 
godine predvidio je "zaštitu života i slobode bez obzira na porijeklo, narodnost, jezik, rasu ili vjeru” za sve stanovnike Kraljevine (čl. 2.). ${ }^{36}$ Osim navedenog, tim je zakonom priznato državljanstvo Kraljevine SHS svim pripadnicima manjina ako su ga stekli na temelju mirovnih ugovora (čl. 3.). Nadalje, zakonom je propisano načelo rođenja na teritoriju (ius soli) kao osnova za priznanje državljanstva Kraljevine SHS za sve osobe "koje se ne mogu pozvati ni na koje drugo državljanstvo po rođenju” (čl. 6.), iako ishođenje priznanja državljanstva temeljem tog članka nije uvijek bilo uspješno za niz osoba. ${ }^{37}$ Zakonom o zaštiti manjina također je propisana jednakost svih državljana Kraljevine SHS “bez obzira na rasu, jezik ili vjeru." (čl. 7.).

\section{NATURALIZACIJE U KRALJEVINI SHS DO STUPANJA NA SNAGU ZAKONA O DRŽAVLJANSTVU IZ 1928. GODINE: VAŽNOST NACIONALNE PRIPADNOSTI}

Ubrzo nakon formiranja Kraljevine SHS Ministarstvo unutrašnjih poslova centraliziralo je nadležnosti u pogledu odlučivanja o naturalizacijama. ${ }^{38}$ Režim obustave naturalizacija potrajao je sve do 1924. godine, a razlog je bilo nastojanje vlasti da najprije riješi molbe i opcije na temelju mirovnih ugovora. ${ }^{39}$ Tijekom 1924. godine vlasti su ponovno počele dodjeljivati državljanstvo. ${ }^{40}$

jednica, manjine u velikoj mjeri definirane primjenom kriterija narodnosti i jezika koji je shvaćen kao ključna odrednica kulturne posebnosti. Riga; Kennedy, op cit. u bilj. 20, str. 463.

36 Tekst zakona o zaštiti manjina vidi u: Pirkmajer, op. cit. u bilj. 26, str. 316 - 324.

37 Za primjer vidi negativno rješenje Ministarstva unutrašnjih djela u predmetu Davida Rosnera. HDA ZO VŽ, IV-1 19248/1926; vidi i predmet Štefice Racz. HDA ZO VŽ, IV-1 59733/1926.

38 Na tom je tragu već 21. svibnja 1919. godine ministar unutrašnjih poslova Svetozar Pribičević upozorio Pokrajinsku zemaljsku vladu u Zagrebu da obustavi naturalizacije do daljnjega. Osnovni sadržaj dopisa od 21. svibnja 1919. godine vidi u predmetu Andrije Uhrinčeka. HDA PU OU, sv. V-2 23252/1922.; vidi i predmet Lavoslava Lövyja iz Požege. HDA PU OU, sv. V-2 27526/1922.

39 HDA PU OU, sv. V-2 9041/1923.

40 Ilustrativan je u tom smislu predmet mađarskog državljanina Simona Bruchsteinera, trgovca nastanjenog u Zagrebu. Bruchsteiner je kao i mnogi prije njega tijekom 1924. obaviješten da pričeka s molbom do donošenja jedinstvenog zakona o državljanstvu. Međutim, on prigovara takvoj praksi te ističe da vlasti daju državljanstvo "raznim strancima (...) na osnovu članova 43. i 44. srpskog građanskog zakona" te nadalje konstatira da novi zakon o državljanstvu neće biti skoro donesen. Zbog toga on ponovno moli dodjelu državljanstva Kraljevine SHS te konačno uspijeva 
Na temelju brojnih dosjea moguće je zaključiti da je hrvatska, slovenska odnosno srpska nacionalna pripadnost bila vrlo značajna kod naturalizacija. Za primjer možemo navesti predmet naturalizacije Ivana Urbančića, talijanskog državljanina i istarskog emigranta u Zagrebu, do koje je došlo 1927. godine. U tom je predmetu veliki župan Zagrebačke oblasti u dopisu Ministarstvu unutrašnjih djela preporučio pozitivno rješenje molbe "tim više što je molitelj porijeklom i jezikom Slovenac". ${ }^{41}$

Osim Hrvata, Srba i Slovenaca u razdoblju od 1925. godine pa sve do donošenja Zakona o državljanstvu 1928. godine naturalizirani su i drugi Slaveni. Slaveni su smatrani poželjnim državljanima ako su se dobro vladali, ako su se bili sposobni uzdržavati, ako su određeno vrijeme bili nastanjeni u zemlji te ako vlasti nisu sumnjale u njihovu lojalnost. Vlasti Kraljevine SHS pod tim su pretpostavkama bile sklone naturalizirati čehoslovačke državljane slavenskog porijekla te ruske državljane slavenskog porijekla. ${ }^{42}$

Uz Srbe, Hrvate i Slovence te ostale Slavene vlasti Kraljevine SHS pod pretpostavkom dobrog vladanja, sposobnosti uzdržavanja, duljine boravka te dokazane visoke akulturacije, bile su sklone naturalizirati i pripadnike ostalih nacija. U tom smislu je ilustrativan predmet naturalizacije mađarskog državljanina i željezničkog činovnika Julija Aignera kojem je opcija odbijena zato što nije "Srbin, Hrvat ili Slovenac po plemenu i jeziku", no koji je zatim 1923. godine podnio molbu za stjecanje državljanstva Kraljevine SHS. Aigner je u molbi naveo da je odbio optirati za Ugarsku, da čitav život živi na teritoriju Kraljevine SHS, da je "upoznao ljude i običaje, posvema se udomaćio, a nadasve (...) kako je oženio domaću kćerku” te da osjeća “ljubav i vjernost prema državi SHS”. Molba Julija Aignera popraćena je i dopisom ravnatelja državnih željeznica kojim se on zauzima za njegovu naturalizaciju istaknuvši da je on "svojevoljno ostao po odlasku Mađara” te da je vrlo sposoban i marljiv. Konačno je Julije Aigner naturaliziran dekretom Ministarstva unutrašnjih djela od 5. svibnja 1924. godine. ${ }^{43}$

Prethodna izlaganja upućuju na važnost hrvatske, srpske i slovenske nacionalne pripadnosti za naturalizaciju. Uz navedeno, također je za naturalizaciju bila značajna i šira slavenska pripadnost. Mogućnost naturalizacije otvorena je i za

biti primljen za državljanina početkom 1925. godine. HDA ZP BH, dosje 25426 (Bruchsteiner).

41 HDA ZO VŽ, IV-1 1192/1927.

42 Vidi naturalizaciju čehoslovačkog državljanina Viktora Koudelke, sveučilišnog profesora nastanjenog u Zagrebu. HDA ZO VŽ, IV-1 14936/26; HDA ZP BH, dosje 28038 (Baba). Za naturalizaciju ruskih državljana vidi HDA ZP BH, dosje 27400 (Alferjev); HDA ZP BH, dosje 28209 (Bjeulosov).

43 HDA ZP BH, dosje 27076 (Aigner). 
pripadnike ostalih naroda, no pod pretpostavkom duljeg boravka i postignutog visokog stupnja akulturacije.

\section{ZAKON O DRŽAVLJANSTVU KRALJEVINE SHS IZ 1928. GODINE I NACIONALNA PRIPADNOST}

Stupanjem na snagu Zakona o državljanstvu Kraljevine SHS 1. studenoga 1928. godine propisana su detaljna pravila za utvrđivanja tzv. početnog državljanskog tijela, unificiran je sustav stjecanja i gubitka državljanstva te su prestali vrijediti ranije doneseni propisi o državljanstvu do tada na snazi na pojedinim pravnim područjima. ${ }^{44}$

Analiza teksta Zakona o državljanstvu pokazuje da je hrvatska, srpska odnosno slovenska nacionalna pripadnost bila vrlo značajna u nizu instituta. ${ }^{45}$ Tako je već prilikom utvrđivanja početnih državljana Kraljevine SHS zakonom propisano da su državljani i svi "po rodu i jeziku Srbi, Hrvati i Slovenci" koji ispunjavaju minimalne zakonske pretpostavke za naturalizaciju pod pretpostavkom da su do dana stupanja na snagu Zakona o državljanstvu podnijeli molbu za stjecanje državljanstva (čl. 53. t. 4.). Zakonom o državljanstvu također je pro futuro predviđena olakšana naturalizacija Slovenaca, Hrvata i Srba ako su zamolili prijam u državljanstvo te ako su navršili 21 godinu, ako su se dobro vladali i ako su se mogli uzdržavati (čl. 12.). U tom slučaju nije se tražilo prethodno prebivanje u Kraljevini. ${ }^{46}$ Konačno, u prijelaznim odredbama Zakona o državljanstvu Kraljevine SHS uređen je institut repatrijacije svih Srba, Hrvata i Slovenaca koji su ranije izgubili državljanstvo odsutnošću. Njima je omogućeno da u sljedećih deset godina na temelju posebne izjave steknu državljanstvo Kraljevine SHS (čl. 57.).

44 Tekst zakona s komentarom vidi u: Pirkmajer, op. cit. u bilj. 26, str. 39 - 135.; Cavalieri, C., Propisi o državljanstvu Kraljevine Srba, Hrvata i Slovenaca, vlastita naklada, Zagreb, 1929., str. 1 - 121.

45 Prema Uredbi ministra unutrašnjih djela od 28. prosinca 1928. godine hrvatska, srpska odnosno slovenska narodnost mogla se dokazivati potvrdom vlasti o tome da je osoba prije 1. prosinca 1918. godine označena kao Hrvat, Srbin ili Slovenac u službenim aktima, u popisu stanovništva, odnosno da je u popisu stanovništva navedeno da se osoba redovito koristi srpskim, hrvatskim ili slovenskim jezikom. Narodnost se također mogla dokazati i školskim svjedodžbama ili, primjerice, potvrdom neke od nacionalnih organizacija (čl. 27. t. 1 - 6). Tekst Uredbe ministra unutrašnjih poslova za izvršenje Zakona o državljanstvu od 28. prosinca 1928. godine vidi u: Pirkmajer, op. cit. u bilj. 26, str. $139-211$.

46 Pirkmajer, op. cit. u bilj. 26, str. 58. 
Osim Hrvata, Srba i Slovenaca, u drugom su stupnju favorizirani i ostali Slaveni. Tako su Zakonom o državljanstvu kao početni državljani Kraljevine SHS priznati i svi "po rodu i jeziku Slaveni” ako su živjeli na teritorijima Kraljevine SHS najmanje dvadeset godina te ako su podnijeli zahtjev za naturalizaciju (čl. 53. t. 5). Nadalje, kao državljani su priznati i svi "po rodu i jeziku Slaveni” nastanjeni u Kraljevini najmanje pet godina ako su za to vrijeme bili u državnoj službi Kraljevine SHS najmanje dvije godine odnosno ako su trenutačno u državnoj službi te ako su zatražili državljanstvo (čl. 53. t. 6). ${ }^{47}$ Izvanredna naturalizacija bez nužnosti ispunjavanja desetogodišnjeg roka nastanjenja u zemlji predviđena je i za ruske izbjeglice u Kraljevini SHS ako su slavenskog porijekla (čl. 58. t. 2). ${ }^{48}$

Osim prethodno navedenih pravila, Zakonom o državljanstvu propisana su "nacionalno neutralna” pravila za utvrđivanje državljanstva. Tako su Zakonom o državljanstvu kao državljani priznati svi koji su 1. prosinca 1918. godine bili državljani Kraljevine Srbije, Crne Gore te svi koji su imali državljanstvo u Kraljevini Hrvatskoj i Slavoniji, a nisu ga izgubili mirovnim ugovorima. Državljanstvo je također priznato svima koji su ga stekli na temelju mirovnih ugovora (čl. 53. t. 1 - 2). Nadalje, Zakonom o državljanstvu kao državljani priznati su svi koji su državljanstvo stekli naturalizacijom (čl. 53. t. 3). Zakonom je također državljanstvo priznato i određenim kategorijama osoba za koje se pretpostavljalo da su se asimilirale. Tako su kao državljani u pravilu priznati svi stranci zaposleni $\mathrm{u}$ javnim ustanovama i prometnim poduzećima koja je Kraljevina SHS preuzela pod svoju upravu, pod pretpostavkom da su zatražili dodjelu državljanstva (čl. 53. t. 7). Neovisno o primjeni nacionalnog kriterija kao državljani priznati su i svi koji su neprekidno prebivali na teritoriju Kraljevine SHS tijekom trideset godina uz pretpostavku da su upravnim vlastima predali posebnu izjavu u kojoj izražavaju namjeru da žele biti državljani Kraljevine SHS (čl. 53. t. 8). Neovisno o nacionalnom kriteriju državljanstvo je priznato i svim apatridima rođenima u Kraljevini (čl. 53. t. 10). ${ }^{49}$ Nadalje, državljanstvo je priznato i svim stanovnicima Turske Carevine koji su balkanskim ratovima ušli u sastav Kraljevine Srbije odnosno Kraljevine Crne Gore pod pretpostavkom da su stanovali na anektiranim područjima 1913. godine te da su zadržali prebivalište na tim prostorima do 1. prosinca 1918. godine (čl. 55. st. 2.).

47 Vidi predmet priznanja državljanstva Kraljevine SHS ruskom državljaninu slavenskog porijekla Romanu Baljvi, zaposleniku Anatomskog instituta u Zagrebu. Baljva je priznat za državljanina odlukom velikog župana Zagrebačke oblasti u Zagrebu od 27. travnja 1929. HDA ZP BH, dosje 28071 (Baljva).

HDA ZP BH, dosje 27064 (Abramović).

49 Za primjer utvrđivanja državljanstva na temelju ius soli vidi HDA ZP BH, dosje 27419 (Ambruš). 
Zakonom o državljanstvu uređen je institut redovite naturalizacije na temelju koje su državljanstvo mogli steći strani državljani ako su ispunili zakonske pretpostavke i ako im je Ministarstvo unutrašnjih djela na temelju diskrecijske ocjene dodijelilo državljanstvo. Strani državljani u molbi su trebali dokazati neprekinuti boravak u Kraljevini u trajanju od najmanje deset godina, da su otpušteni iz dotadašnjeg državljanstva, da su dobrog vladanja, da se mogu uzdržavati te da im je osiguran primitak u zavičajnost neke od općina (čl. 12.). Osim instituta redovite naturalizacije, zakonom je uređena izvanredna naturalizacija predviđena za strance koji nisu ispunjavali pretpostavku desetogodišnjeg prebivanja u Kraljevini ni pretpostavku narodnosti. ${ }^{50}$ Zakonom je također predviđeno pravo na naturalizaciju svih koji su ispunjavali pretpostavke za redovitu naturalizaciju te su na teritoriju Kraljevine SHS prebivali neprekidno trideset godina, uz pretpostavku da zadnjih deset godina nisu ispunjavali obveze prema dotadašnjoj domovini (čl. 13.). U tom slučaju ministar unutrašnjih djela bio je pravno vezan prilikom donošenja odluke. Naposljetku, Zakonom o državljanstvu uređeno je stjecanje državljanstva rođenjem na teritoriju (ius soli) pod pretpostavkom da državljanstvo djetetovih roditelja nije poznato (čl. 9.).

S obzirom na sve navedeno možemo zaključiti da je Zakonom o državljanstvu veza državljanstva i nacionalne pripadnosti definirana na način da je vidljivo favoriziranje Srba, Hrvata i Slovenaca prilikom temeljnog određenja državljanskog tijela, kod naturalizacije te kod repatrijacije. Nadalje, u određenoj mjeri favorizirani su i ostali Slaveni, među kojima izrijekom ruske izbjeglice. Konačno, Zakon je omogućio priznanje državljanstva odnosno naturalizaciju i ostalima, neovisno o kriteriju nacionalne pripadnosti, pod pretpostavkama duljeg nastanjenja na teritoriju, obavljanja javne službe u Kraljevini odnosno rođenja.

\section{NATURALIZACIJE OD 1928. DO 1941. GODINE}

Tijekom 13 godina primjene Zakona o državljanstvu iz 1928. godine u upravnoj praksi primjetna je snažna veza između nacionalne pripadnosti i državljanstva. Niz slučajeva upućuje na zaključak da su pojedinci u postupcima naturalizacija dokazivali narodnost, odnosno da su upravne vlasti procjenjivale narodnost podnositelja. ${ }^{51}$ Pri tome su s obzirom na odredbe Zakona o držav-

50 Na taj način državljanstvo su mogli steći strani državljani “koji dobiju javnu službu na jednom Univerzitetu Kraljevine” ili, primjerice, osobe “čiji prijem u državljanstvo iziskuju državni interesi." (čl. 14.).

51 Na tipiziranom obrascu za stjecanje državljanstva predviđena je posebna rubrika u koju je trebalo upisati porijeklo. Opasku "Jugoslaven" vidi u predmetu HDA ZP BH, dosje 25386 (Brauner); opasku “Slaven Rus” vidi u HDA ZP BH, dosje 25376 
ljanstvu iz 1928. godine u postupcima naturalizacija favorizirani Hrvati, Srbi i Slovenci koji su od 1929. godine, s obzirom na službenu doktrinu jugoslavenske nacije, u spisima često nazivani Jugoslavenima. ${ }^{52}$ Politiku favoriziranja Hrvata, Srba i Slovenaca potkraj razdoblja potvrdila je i Banska vlada Banovine Hrvatske u uputama izdanim tijekom 1940. godine. Uputama je Banska vlada upozorila podređena upravna tijela na nužnost osobitih obzira u predmetima državljanstva u kojima su stranke Hrvati, Srbi i Slovenci te "u obzira vrijednim slučajevima" ostali Slaveni. ${ }^{53}$ Jedan takav "obzira vrijedan slučaj” zasigurno je bio predmet naturalizacije Nikole Vasilija Arnautova iz 1940. godine. Arnautov je bio bugarski državljanin koji je bugarsko državljanstvo stekao po ocu, bugarskom državljaninu i Bugarinu po narodnosti. U njegovu su predmetu, osim činjenice da mu je otac Bugarin, upravne vlasti kao ključno navele da mu je majka Hrvatica, da je rođen na teritoriju Kraljevine Jugoslavije 1916. godine te da je on "po porijeklu Bugarin, a po narodnosti Hrvat, jer se ovdje rodio i odgojio od majke Hrvatice i sve škole ovdje svršio dok u Bugarskoj uopće nije bio". ${ }^{44}$

Nacionalna skupina prema kojoj su vlasti u načelu imale blagonaklon stav bili su ruski emigranti nastanjeni u Kraljevini. S obzirom na njihovo slavensko porijeklo vlasti su smatrale da je njihova akulturacija lakša. Na temelju niza pregledanih slučajeva moguće je zaključivati da su molbe za naturalizacijom tih stranaca u pravilu bile pozitivno rješavane. U većini slučajeva ovi su stranci u molbama dokazivali da ispunjavaju pretpostavke za redovitu naturalizaciju među kojima je bila i pretpostavka desetogodišnjeg nastanjenja u Kraljevini. ${ }^{55}$ Međutim, s obzirom na odredbe Zakona o državljanstvu moguća je bila i izvanredna naturalizacija ruskih emigranata bez desetogodišnjeg nastanjenja u zemlji, no u tom slučaju odluku o naturalizaciji je umjesto ministra unutrašnjih djela donosio Ministarski savjet. Osim prema ruskim emigrantima, upravne vlasti Kraljevine Jugoslavije u načelu su bile blagonaklone i prema naturalizaciji dotadašnjih čehoslovačkih državljana slavenskog porijekla. ${ }^{56}$

(Bratanovsky); opasku “Slaven” “porijeklom Čeh" vidi u HDA ZP BH, dosje 28198 (Bilek); opasku "Neslaven - Jevrejin" vidi u predmetu HDA ZP BH, dosje 27684 (Mayer).

HDA ZP BH, dosje 28208 (Bizjak); HDA ZP BH, dosje 28186 (Bertoša); HDA ZP $\mathrm{BH}$, dosje 25386 (Brauner).

HR Hrvatski državni arhiv, Banovina Hrvatska, Odjel za unutarnje poslove, fond 157, kutija 3, pov. I-3 690/1940.

HDA ZP BH, dosje 27449 (Arnautov).

HDA ZP BH, dosje 27431 (Andenkov); HDA ZP BH, dosje 28165 (Berger, Pavao); HDA ZP BH, dosje 27074 (Afonasjev). 
Bitno teže od ruskih emigranata te čehoslovačkih državljana slavenskog porijekla državljanstvo su stjecali Židovi. Analiza pojedinačnih zahtjeva za redovitom naturalizacijom pokazuje da je Ministarstvo unutrašnjih djela u nizu predmeta odbilo naturalizirati Židove zbog nedovoljnog stupnja akulturacije. Pri tome je jedan od glavnih prigovora bilo nedovoljno dobro poznavanje hrvatsko-srpskog jezika. ${ }^{57}$ Ponekad su odbijeni podnositelji ponavljali molbe za naturalizacijom te su u konačnici bili i uspješni. Ilustrativan u tom smislu je predmet Jakoba Weinsteina, ravnatelja industrijskog i trgovačkog poduzeća u Zagrebu, nastanjenog u Zagrebu od 1920. godine. Ocjenjujući njegovu molbu tijekom 1932. godine, Banska uprava Savske banovine Ministarstvu unutrašnjih djela preporučila je negativno rješenje te je u konačnici njegova molba odbijena. Kao negativna okolnost i razlog odbijanja molbe upravne vlasti su navele nedovoljnu prilagodbu "sadanjem stanju i našem življu" te činjenicu da podnositelj "slabo vlada našim jezikom". Negativno rješenje molbe nije međutim spriječilo Weinsteina da i dalje podnosi molbe za naturalizaciju te da konačno 1940. godine stekne državljanstvo Kraljevine Jugoslavije. Među razlozima za naturalizaciju Banska vlada Banovine Hrvatske navela je kontinuirano boravište u Kraljevini od 1922. godine, dobro vladanje, sposobnost uzdržavanja, zajamčenu zavičajnost u općini grada Zagreba te preporuku upravnih vlasti. ${ }^{58}$ Donekle sličan primjer višestrukog pokušaja stjecanja državljanstva je i slučaj austrijskog Židova Makse Mayera, rođenog 1888. godine u Mattersburgu u Burgenlandu, koji je boravio na teritoriju Kraljevine Jugoslavije od 1918. godine. Mayer prvotno nije uspio sa zahtjevom za opciju tijekom 1922. godine te je tek u drugom pokušaju tijekom 1935. godine njegova molba pozitivno riješena. U njegovu predmetu upravne su vlasti ocjenjivale njegovo dotadašnje ponašanje te stupanj akulturacije. Bitna osnova za pozitivno rješenje molbe bilo je mišljenje policije u Zagrebu o tome da se molitelj prilagodio "sadanjem stanju i našem življu" te da "vlada dobro našim jezikom i da obrazuje kćer u narodnom duhu". ${ }^{9}$

Određeno ograničenje upravnim vlastima u procjenjivanju stupnja akulturacije stranaca predstavljao je institut prava na državljanstvo nakon trideset godina prebivanja u Kraljevini. Na temelju niza pregledanih predmeta moguće je zaključiti da su upravo na tom temelju brojni stranci, a osobito mnogi Židovi, stekli državljanstvo. ${ }^{60}$ Ilustrativan je predmet Izidora Abrahamsohna, Židova iz

57 HDA ZP BH, dosje 27061 (Abend); HDA ZP BH, dosje 27065 (Acel-Aczel); HDA ZP BH, dosje 28162 (Berger, Eugen).

58 HDA ZP BH, dosje 24638 (Weinstein).

59 HDA ZP BH, dosje 27684 (Mayer).

60 Za slučaj stjecanja državljanstva čehoslovačkog državljanina vidi HDA ZP BH, dosje 28197 (Bilek, Karla Franjo). Za slučaj stjecanja državljanstva mađarske državljanke 
Rumunjske, rođenog u Osijeku 1894. godine, koji je s obzirom da ga rumunjske vlasti nisu priznavale za državljanina bio apolit. Abrahamsohn je podnio zahtjev za naturalizacijom temeljeći zahtjev na činjenici da je više od 30 godina nastanjen u Kraljevini Jugoslaviji. U postupku naturalizacije u izvještaju od 15. rujna 1931. godine Predstojništvo gradske policije u Osijeku navelo je da Izidor Abrahamsohn po dotadašnjem općem i političkom ponašanju zaslužuje primitak u državljanstvo. Konačno mu je nadležna Banska uprava Savske banovine 1932. godine dodijelila državljanstvo Kraljevine Jugoslavije. ${ }^{61}$

Naposljetku, s obzirom na sve navedeno, možemo zaključiti da su prilikom ocjenjivanja pojedinih molbi upravne vlasti uzimale u obzir narodnu pripadnost te su također u slučaju ostalih Slavena, a još više u slučaju podnositelja koji nisu bili Slaveni, usporedno s porijeklom procjenjivale i postignut stupanj akulturacije podnositelja. Pri tome su za procjenu stupnja akulturacije osobito značajni bili kriteriji duljine boravka u zemlji, prilagodbe sredini te poznavanje jezika.

\section{ZAKLJUČAK}

Provedena analiza odnosa državljanstva i nacionalne pripadnosti pokazuje da je do pomicanja u smjeru isključujućeg izvornog tipa državljanstva na područjima koja su ušla u sastav Kraljevine SHS došlo i prije 1918. godine. Osim tradicije, ključan moment za uspostavu isključujućeg izvornog tipa u Kraljevini SHS u razdoblju do donošenja Zakona o državljanstvu iz 1928. godine bili su mirovni ugovori koji su sadržavali i pravila o opciji koja su se temeljila na rasnoj odnosno narodnoj pripadnosti te jeziku. Analiza upravne prakse naturalizacija pri tome pokazuje da izvornost nije jednoznačno definirana. Provedena analiza pokazuje da su u prvom stupnju favorizirani Hrvati, Srbi i Slovenci, dok su u drugom stupnju favorizirani ostali Slaveni. S obzirom na to, isključujući izvorni tip bi pravilnije bilo nazvati isključujućim dvostupanjskim izvornim tipom. Ovako uspostavljen tip odnosa državljanstva i nacionalne pripadnosti trpio je određene korekcije u pogledu isključivosti i izvornosti. Bitna korekcija u pogledu isključivosti bio je Zakon o zaštiti manjina, posebno njegova odredba o jednakosti svih državljana bez obzira na narodnost, jezik ili vjeru. Izvornost je kao kriterij ulaska u zajednicu državljana također bila ublažena tako što je stjecanje državljanstva omogućeno i strancima koji su dokazali visok stupanj akulturacije, dakle naučenog ponašanja.

vidi HDA ZP BH, dosje 28200 (Bing). Za slučaj stjecanja državljanstva Židova vidi HDA ZP BH, dosje 27424 (Anderman Wolf); HDA ZP BH, dosje 27404 (Alt); HDA ZP BH, dosje 28205 (Bittel). 
Zakon o državljanstvu Kraljevine SHS iz 1928. godine u osnovi je slijedio raniji razvoj te je sadržavao kriterije hrvatske, srpske odnosno slovenske narodne pripadnosti kao značajne za utvrđivanje i stjecanje državljanstva te za repatrijaciju. Zakonom su popisani i dodatni kriteriji primjenom kojih su u drugom stupnju bili privilegirani i ostali Slaveni. Na taj je način kao i ranije zadržan isključujući dvostupanjski izvorni tip. Svojevrsnu korekciju izvornosti predstavljali su instituti predviđeni Zakonom o državljanstvu primjenom kojih je bio moguć ulazak u zajednicu državljana i ostalim strancima koji nisu udovoljavali kriteriju nacionalne pripadnosti ako su usvojili specifičan obrazac ponašanja. Pri tome su ključna obilježja tog obrasca bili dulji boravak u zemlji, obrazovanje u zemlji te dobro poznavanje jezika. Konačno, bitna korekcija isključujućeg tipa državljanstva bio je i otprije važeći Zakon o zaštiti manjina.

\section{IZVORI}

HR Hrvatski državni arhiv, Pokrajinska uprava za Hrvatsku i Slavoniju u Zagrebu, Odjeljenje za unutarnje poslove.

HR Hrvatski državni arhiv, Zagrebačka oblast, Veliki župan, fond 141.

HR Hrvatski državni arhiv, Banovina Hrvatska, Odjel za unutarnje poslove, fond 157.

HR Hrvatski državni arhiv, Zbirka personalija Banovine Hrvatske, fond 890.

Ustav Kraljevine Srba, Hrvata i Slovenaca, obnarodovan u br. 142a „Službenih Novina“ na Vidovdan 28. juna 1921. god. u Beogradu, Državna štamparija Kraljevine Srba, Hrvata i Slovenaca, Beograd, 1926.

Zakonski članak L.:1879. zajedničkoga hrvatsko-ugarskoga sabora o stečenju i gubitku ugarskoga državljanstva, u: Sbornik zakonah $i$ naredabah valjanih za kraljevinu Hrvatsku i Slavoniju, komad VII., 1880.

Ustav Kneževine Crne Gore iz 1905. godine: http://www.montenegrina.net/ pages/pagesl/istorija/dokumenti/Ustav\%20Crne\%20Gore\%20iz\%201905. pdf (pristup 1.1.2018.).

\section{LITERATURA}

Banac, Ivo, Nacionalno pitanje u Jugoslaviji: porijeklo, povijest, politika, Globus, Zagreb, 1988.

Brubaker, Rogers, Citizenship and Nationhood in France and Germany, Harvard University Press, Cambridge, Massachusetts and London, England, Second printing, 1994. 
Cavalieri, Celso, Propisi o državljanstvu Kraljevine Srba, Hrvata i Slovenaca, Vlastita naklada, Zagreb, 1929.

Čepulo, Dalibor, Prava građana i moderne institucije: europska i hrvatska pravna tradicija, Pravni fakultet Sveučilišta u Zagrebu, Zagreb, 2003.

Fahrmeir, Andreas, Citizenship: The Rise and Fall of a Modern Concept, Yale University Press, New Haven and London, 2007.

Gammerl, Benno, Subjects, citizens and others: the handling of ethnic differences in the British and the Habsburg Empires (late nineteenth and early twentieth century), European Review of History - Revue européenne d'histoire, vol. 16, br. 4, 2009., str. 523 - 549.

Goldstein, Ivo, Hrvatska 1918-2008., EPH Liber, Zagreb, 2008.

Gosewinkel, Dieter, Einbürgern und Ausschliessen: Die Nationalisierung der Staatsangehörigkeit vom Deutschen Bund bis zur Bundesrepublik Deutschland, Vandenhoeck \& Ruprecht, Göttingen, 2003.

Fink, Carole, The Paris Peace Conference and the Question of Minority Rights, Peace \& Change, vol. 21, br. 3, 1996., str. 273 - 288.

Healy, Maureen, Becoming Austrian: Women, the State, and Citizenship in World War I, Central European History, vol. 35, br. 1, 2002., str. 1 - 35.

Hirschhausen, Ulrike, From imperial inclusion to national exclusion: citizenship in the Habsburg monarchy and in Austria 1867-1923, European Review of History Revue européenne d'histoire, vol. 16, br. 4, 2009., str. 551 - 573.

Jenson, Jane, Place-Sensitive Citizenship: The Canadian Citizenship Regime until 1945, u: Hoerder, Dirk; Harzig, Christiane; Shubert Adrian, The Historical Practice of Diversity: Transcultural Interactions from the Early Modern Mediterranean to the Postcolonial World, Berghahn Books, New York, Oxford, 2003., str. $221-238$.

Joppke, Christian, Transformation of Citizenship: Status, Rights, Identity, Citizenship Studies, vol. 11, br. 1, 2007., str. $37-48$.

Katunarić, Vjeran, Sporna zajednica: novije teorije o naciji i nacionalizmu, Jesenski i Turk, Hrvatsko sociološko društvo, Zagreb, 2003.

Kosnica, Ivan, Citizenship in Croatia-Slavonia during the First World War, Journal on European History of Law, vol. 8, br. 1, 2017., str. 58 - 65.

Kosnica, Ivan, Naturalizacija u Hrvatskoj i Slavoniji od 1848. do 1918., Zbornik Pravnog fakulteta Sveučilišta u Rijeci, vol. 34, br. 2, 2013., str. 701 - 728.

Macartney, C. A., The Habsburg Empire, Weidenfeld and Nicolson, London, 1971. Pirkmajer, Otomar, Zakon o državljanstvu sa tumačenjem, Gece Kona, Beograd, 1929. 
Riga, Liliana; Kennedy, James, Tolerant majorities, loyal minorities and "ethnic reversals": constructing minority rights at Versailles, Nations and Nationalism, vol. 15, br. 3, 2009., str. $461-482$.

Sammartino, Annemarie, After Brubaker: Citizenship in Modern Germany, 1848 to Today, German History, vol. 27, br. 4, 2009., str. 583 - 599.

Smith, Anthony D., Nacionalizam i modernizam: kritički pregled suvremenih teorija nacija i nacionalizma, Politička misao, Zagreb, 2003.

$\mathrm{Su}$, Anna, Woodrow Wilson and the Origins of the International Law of Religious Freedom, Journal of the History of International Law, vol. 15, br. 2, 2013. str. $235-267$.

Štiks, Igor, Nations and Citizens in Yugoslavia and the Post-Yugoslav States: One Hundred Years of Citizenship, Bloomsbury, London-New York, 2015.

Tepić, Đuro; Bašić, Ivan, Zbirka propisa o državljanstvu, Narodne novine, Zagreb, 1969.

Tilly, Charles, Citizenship, Identity and Social History, u: Tilly, Charles (ed.), Citizenship, Identity and Social History, International Review of Social History, Cambridge University Press, Cambridge, 1996., str. 1 - 17.

Tilly, Charles, The Emergence of Citizenship in France and Elsewhere, u: Tilly, Charles (ed.), Citizenship, Identity and Social History, International Review of Social History, Cambridge University Press, Cambridge, 1996., str. 223 - 236.

Troch, Pieter, Yugoslavism between the world wars: indecisive nation building, Nationalities Papers, vol. 38, br. 2, 2010., str. 227 - 244.

Varga, Norbert, The Framing of the First Hungarian Citizenship Law (Act 50 of 1879) and the Acquisition of citizenship, Hungarian Studies, vol. 18, br. 2, 2004., str. $127-151$.

Weil, Patrick, How to be French: Nationality in the Making since 1789, Duke University Press, Durham and London, 2008. 
Summary

\section{Ivan Kosnica *}

\section{RELATION BETWEEN CITIZENSHIP AND NATIONALITY IN THE KINGDOM OF SERBS, CROATS AND SLOVENES/YUGOSLAVIA}

The paper deals with the relation between the concepts of citizenship and nationality in the Kingdom of Serbs, Croats and Slovenes, officially called the Kingdom of Yugoslavia from 1929, in the period from the formation of the state in 1918 until its defeat in the April War in 1941. The basic methodological tool used in the analysis is Charles Tilly's classification into four basic models of relation between citizenship and nationality: the exclusive-primordial, the exclusive-learned, the inclusive-primordial and the inclusive-learned model. The author defines the relation between citizenship and nationality as the exclusive-primordial model. Having in mind the favoring of Serbs, Croats and Slovenes and subsequently other Slavs in the Kingdom of Serbs, Croats and Slovenes, the author points out that this model should be called the exclusive-double primordial model. Key arguments for thesis about the exclusive-double primordial model were, according to the author, numerous acts including the Citizenship Code of 1928 that favored Serbs, Croats and Slovenes and in the second stage other Slavs in the procedures of determination or acquisition of citizenship. The author further points out corrections to the exclusive-double primordial model. An important correction of exclusivity was the Law on minorities which guaranteed equality to all citizens regardless of their nationality, language and religion. The correction of primordiality refers to the practice of naturalization by which the authorities accepted foreigners if an adequate degree of acculturation had been achieved. A key factor in this was the duration of residence in the country and the knowledge of the national language.

Keywords: nationality, citizenship, the Kingdom of SCS, the Kingdom of Yugoslavia, Citizenship Code

Ivan Kosnica, Ph. D., Assistant Professor, Faculty of Law, University of Zagreb, Sv. Ćirila i Metoda 4, Zagreb; ikosnica@gmail.com;

ORCID ID: orcid.org/0000-0002-0467-6062 
